\title{
Neogene to Recent Species of Krithe (Crustacea: Ostracoda) from the Tasman Sea and off Southern Australia with Description of Five New Species
}

\author{
Michael Ayress, ${ }^{1}$ Timothy Barrows, ${ }^{2}$ Vicki Passlow $^{1} \&$ Robin Whatley ${ }^{3}$ \\ ${ }^{1}$ Department of Geology, Australian National University, ACT 0200, Australia \\ Present addresses: M. Ayress, Ichron Limited, 5 Dalby Court, Gadbrook Business Centre, Northwich CW9 7TN, \\ England; Vicki Passlow, Australian Geological Survey Organisation, GPO Box 378, Canberra ACT 2601 \\ ayress@ichron.com・vicki.passlow@agso.gov.au \\ ${ }^{2}$ Research School of Earth Sciences, Australian National University, ACT 0200, Australia \\ tim.barrows@rses.anu.edu.au \\ ${ }^{3}$ Unit of Micropalaeontology, University of Wales, Aberystwyth SY23 3DB, England \\ riw@aber.ac.uk
}

\begin{abstract}
The ostracod genus Krithe is reported from four grab, two box-core, 62 coretop samples, and Neogene to Quaternary DSDP cores from the abyssal and bathyal regions of the Tasman Sea and off southern Australia. Species identification followed the taxonomic system proposed by Coles et al. (1994), in which the anterodorsal radial pore canals are of fundamental importance. A total of 19 species are recognised, five species are described as new: K. comma, K. dilata, K. pseudocomma, K. prolata, and $K$. triangularis. Fifteen species are referred to previously described species, and the remaining rare species are left in open nomenclature. Although no living specimens have been recovered, shells of all species have been found in modern sediments and are, therefore, considered to be extant. Overall, the stratigraphic distribution of the species demonstrates an increase in diversity from 3 to 19 species since the Early Miocene, with no extinction. The bathymetric range of most species is wide, though in certain species there are significant differences between the two study regions, such as on the Australian Continental Slope, the relatively much deeper occurrences of $K$. triangularis and $K$. marialuisae, and the absence of $K$. dolichodeira a species found commonly elsewhere. An explanation for such differences is most likely to relate to nutrient, substrate, and oceanographic differences between the two regions.
\end{abstract}

Ayress, Michael, Timothy Barrows, Vicki Passlow \& Robin Whatley, 1999. Neogene to Recent species of Krithe (Crustacea: Ostracoda) from the Tasman Sea and off southern Australia with description of five new species. Records of the Australian Museum 51(1): 1-22. 